\title{
DISCHARGE RELATION FOR SMALL PARSHALL FLUME IN FREE FLOW CONDITION
}

\author{
Jalam Singh $^{1}$, S.K.Mittal ${ }^{2}$, H.L.Tiwari ${ }^{3}$ \\ ${ }^{I}$ M.Tech. Student, Civil Engg. Dept, MANIT Bhopal (M.P.), India \\ ${ }^{2}$ Professor, Civil Engg, Dept, MANIT Bhopal (M.P.), India \\ ${ }^{3}$ Asst.Professor, Civil Engg, Dept, MANIT Bhopal (M.P.), India
}

\begin{abstract}
Good water measurement systems enable accurate accounting of water use and permit the available water to be supplied at optimum rates to the areas where it is intended to be used. A Parshall Flume is normally used as flow measuring device for open-channel flow. It is suitable to ease of manufacture and installation. At the point of measurement there is much work has attempted to calibrate and develop a discharge relation equation for large Parshall Flume. Hence, accurate relation between discharge and upstream head valid for small sizes of Parshall flume is required. In present paper four different sizes of Parshall flumes, having different throat width fabricated and tested in the laboratory under free-flow condition. Coefficient of discharge and exponent are determined by using MATLAB programming and developed a single equation for the different flume sizes. The relation is simple and suitable to use for the small Parshall Flume.
\end{abstract}

Keywords: Parshall Flume, Free flow, MATLAB, Flumes, Water measurement

*** $*$

\section{INTRODUCTION}

Improvement of water management can encourage conservation and makes best use of our limited water resources. Water management depends upon the ability to precisely measure and manage the flow of water at important points in a river basin or irrigation system [8]. Many devices and structure have been developed for the measuring discharge but measuring flume are one of the most accepted and used structure. Irrigation water frequently contains sediment or other undesirable materials such as sediment in the water may be deposited in irrigation ditches, pipelines, and measuring structures [8]. This necessitates frequent ditch cleaning and often results in inaccurate flow measurement. Garbage in irrigation water might be a source of weed influx on the farm it also clogs minor irrigation structures. Such Structures are needed to remove trash and excess sediment from the water.

A Parshall flume consists of a converging section, a throat section and diverging section. The crest of the throat section is tilted downstream. In other words, there is a sill between the horizontal crest, converging section and the crest of the throat section [14]. For channels smaller than $2.44 \mathrm{~m}$ the inlet of the converging section may be rounded and larger channels may have vertical walls at a $45^{\circ}$ angle. To prevent erosion due to water fall the diverging section is usually extended by means of vertical walls and the angle of these walls will be steeper than the angle of the walls of the diverging section.

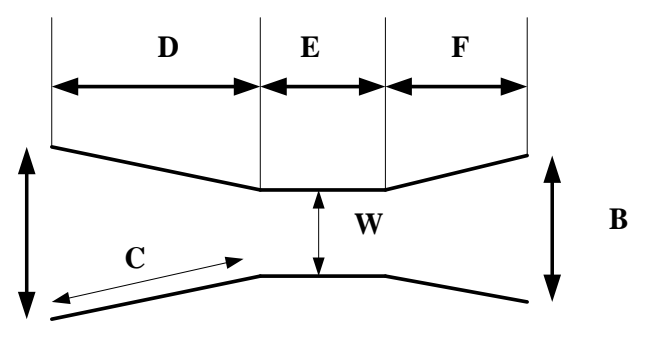

Fig 1: Plan view of Parshall Flume

Many works has been prepared with the Parshall Flume for large size and developed discharge rating equation basis on the experimental data obtained from past researchers. In 1917, Cone [9] developed Venturi flume which was either rectangular or trapezoidal in cross sectional area and consist of converging and diverging section, with a short throat section between them. The floor of the Venturi flume was level and placed at the elevation of the grade of the channel. In 1928 Parshall [14] attempt study on Improved Venturi flume and found that it operates effectively with relatively slight loss of head and because of the enlarged velocity of the water in the flume, it works successfully in sand- or silt-laden streams . Discharge equation for Parshall flume is given as:

$$
\mathrm{Q}=4 \mathrm{WHa}{ }^{1.522 \mathrm{~W}^{0.026}}
$$


In 1966, Skogerboe et al. [16] prepared calibration curve for the free flow and submerged flow. In this study Parshall flume was tested in the laboratory under free-flow submerged condition. In 1967, Skogerboe et al. [17] studied the parameters which describe submergence in flow measuring flumes and it was developed by a combination of dimensional analysis. In 1990, Abt \& Staker [1] tested a $7.62 \mathrm{~cm}$ Parshall flume in a channel and flow rates are measured with different crest slope. This study resulted with the information that the flow measurement requires a $0.75 \%$ adjustment for each $1 \%$ of lateral arrangement at the flume crest. In 1994, Wright et al [22] developed a numerical model to predict the effect of fluid viscosity on the depth-discharge relationship. The numerical model successfully validated through the experimental data for the flume sizes studied. In 1994, Blaisdell [6] reanalysis that shows the equations presented by Parshall predict the discharge to within the $5 \%$ accuracy claimed by Parshall as well as similar accuracy is obtained using the author's equations. In 2009, Thornton et al [20] conducted an experiment to determine the suitability of measuring supercritical flow by Parshall flume which is basically developed to accurately measure open-channel subcritical flow. This study resulted with that single Parshall flume can be used to measure flow within $\pm 5 \%$ for both supercritical and subcritical flow regimes for a specified range of flows. In 2013, Amanda et al [3] tested a $1.5 \mathrm{~m}$ Parshall Flume with discharge up to $0.854 \mathrm{~m}^{3} / \mathrm{s}$ and Froude numbers changing from $0.67-1.31$. Experiment resulted with three zones on the basis of convergence ratio: (1) subcritical $(0<\mathrm{Cr}<0.6)$, (2) transition $(0.6<\mathrm{Cr}<1.0)$, and (3) supercritical $(\mathrm{Cr}>1.0) \mathrm{On}$ the basis of brief discussion of previous work it would be say that there is not much work attempt for small size flume. The aim of this paper is to establish a single relation equation between head and discharge for small size Parshall Flume.

\section{MATERIAL AND METHODS}

In this study four different sizes of Parshall flumes having throat width of $0.052 \mathrm{~cm}, 0.076 \mathrm{~cm}, 0.152 \mathrm{~cm}$ and $0.229 \mathrm{~cm}$ were used. The dimensions of Parshall flumes used in this study are given in Table 1 . The flumes were installed in a flat bed test channel having a size of $9.45 \times 0.60 \times 0.55 \mathrm{~m}$ at Fluid Mechanics Laboratory situated at Maulana Azad National Institute of Technology, Bhopal. The upstream heads at the upstream location, as specific for a Parshall Flume measured by a vernier type point gauge. The discharge is measured by velocity area method. Velocity was measured by the Pitot tube. The values of measured heads and discharges are given in tabular form in Table 4.

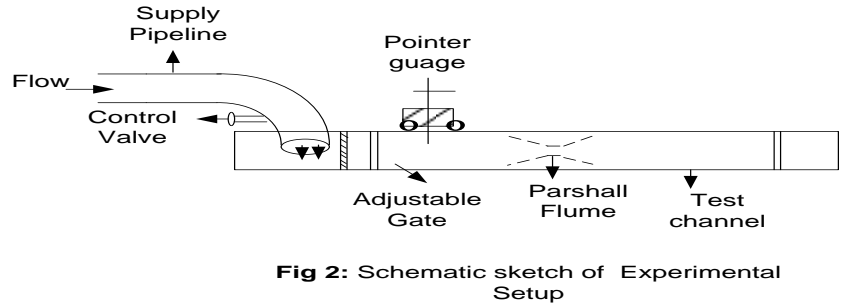

Table 1: Parshall Flume model used in experiments (All dimensions in centimetres)

\begin{tabular}{|l|l|l|l|l|l|l|}
\hline W & A & B & C & D & E & F \\
\hline 5.08 & 21.35 & 13.49 & 41.43 & 40.64 & 11.43 & 25.40 \\
7.62 & 47.23 & 17.78 & 46.63 & 45.72 & 15.24 & 30.48 \\
15.24 & 39.69 & 38.74 & 62.07 & 60.96 & 30,48 & 60.96 \\
22.86 & 57.47 & 38.10 & 87.95 & 86.36 & 30.48 & 45.72 \\
\hline
\end{tabular}

The Parshall Flume used to measure flow rates under two different flow conditions; namely, free flow and submerged flow. The flow equation and the method of flow analysis are different for each type of flow. Under free-flow conditions, discharge through Parshall flume mainly depends on upstream head which can be expressed as:

$$
\mathrm{Q}=\mathrm{CH}^{\mathrm{n}}
$$

Where $\mathrm{Q}=$ discharge through flume, $\mathrm{C}=$ discharge coefficient which is the function of throat width, $\mathrm{H}=$ upstream head measured at $2 / 3$ of converging section from throat and $n=$ exponent of head $\mathrm{H}$.

Equation (1) can be written as following to find the value of C and $\mathrm{n}$

$$
\begin{gathered}
\log Q=\log \left(C^{n}{ }^{n}\right) \\
\log Q=\log C+n \log H
\end{gathered}
$$

If $\log \mathrm{Q}=\mathrm{Y}, \log \mathrm{C}=\mathrm{A}$ and $\log \mathrm{H}=\mathrm{X}$ than

$$
\mathrm{Y}=\mathrm{A}+\mathrm{nX}
$$

In present study MATLAB Programming was used to determine the value of $\mathrm{C}$ and $\mathrm{n}$ as well as Calibration chart prepared by using MATLAB.

Table 2: Analysis of Experimental data

\begin{tabular}{|c|l|l|l|}
\hline \multicolumn{4}{|c|}{ Values } \\
\hline $\mathrm{W}(\mathrm{m})$ & $\mathrm{C}$ & $\mathrm{n}$ & $\mathrm{R}^{2}$ \\
\hline 0.052 & 0.1482 & 1.445 & 0.985 \\
0.076 & 0.232 & 1.368 & 0.623 \\
0.152 & 0.5058 & 1.444 & 0.984 \\
0.229 & 0.681 & 1.410 & 0.968 \\
\hline
\end{tabular}




\section{RESULTS AND DISCUSSION}

Observations for discharges and heads on four Parshall Flume of different sizes are made. In all 37 observations are taken. These are given in Table 4. For different size of Parshall Flume Equation (2) can be written as

$$
\begin{aligned}
& \text { For } 0.052 \mathrm{~m} \text { Flume } \mathrm{Q}=0.1482 \mathrm{H}^{1.445} \ldots \\
& \text { For } 0.076 \mathrm{~m} \text { Flume } \mathrm{Q}=0.232 \mathrm{H}^{1.368} \ldots \\
& \text { For } 0.152 \mathrm{~m} \text { Flume } \quad \mathrm{Q}=0.5058 \mathrm{H}^{1.444} \ldots \\
& \text { For } 0.229 \mathrm{~m} \text { Flume } \mathrm{Q}=0.681 \mathrm{H}^{1.410} \ldots
\end{aligned}
$$

Table 2 shows that equation (3) developed with $\mathrm{R} 2=0.985$, $0.623,0.984$ and 0.968 respectively for equation (4), (5) and (6). It also shows that exponent n varies from 1.368 to 1.445 .

Table 3: Values of constant $\mathrm{C}$ and Exponent $\mathrm{n}$ for Free-flow Discharge through different-size Parshall Flumes

\begin{tabular}{|l|l|l|l|l|l|l|}
\hline \multirow{2}{*}{$\mathrm{W}$} & \multicolumn{4}{|l|}{ Coefficient C } & \multicolumn{3}{l|}{ Exponent $\mathrm{n}$} \\
\cline { 2 - 7 } & $\begin{array}{l}\text { Experi } \\
\mathrm{m}-\mathrm{ent}\end{array}$ & $\begin{array}{l}2.85 \\
\mathrm{~W}\end{array}$ & $\begin{array}{l}\text { Differ } \\
\text { ence }\end{array}$ & $\begin{array}{l}\text { Experi- } \\
\text { ment }\end{array}$ & $\mathrm{n}$ & $\begin{array}{l}\text { Differ } \\
\text { ence }\end{array}$ \\
\hline $0.05 \mathrm{~m}$ & 0.1482 & 0.148 & .0002 & 1.445 & 1.4 & .045 \\
$0.07 \mathrm{~m}$ & 0.232 & 0.216 & .016 & 1.368 & 1.4 & -.032 \\
$0.15 \mathrm{~m}$ & 0.505 & 0.432 & .073 & 1.444 & 1.4 & .044 \\
$0.22 \mathrm{~m}$ & 0.681 & 0.652 & .029 & 1.41 & 1.4 & .01 \\
\hline
\end{tabular}

By assessment of the data in Table 3 it is marked that, as an approximation, $\mathrm{C}=2.85 \mathrm{~W}$, where $\mathrm{W}$ is the width of throat, in meter and slope $\mathrm{n}=1.4$ the relation between $\mathrm{Q}$ and $\mathrm{H}$ for free flow condition has been established as:

$$
\mathrm{Q}_{\mathrm{L}}=2.85 \mathrm{~W} \mathrm{H}^{1.4}
$$

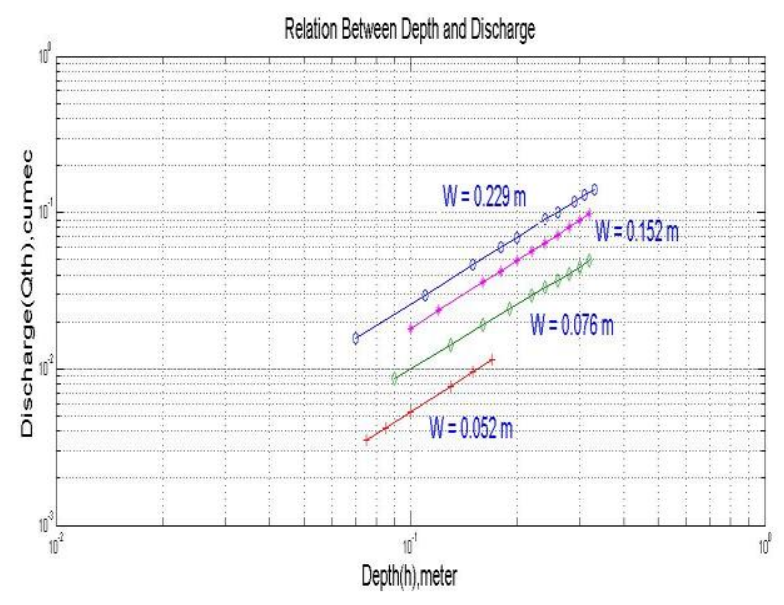

Chart 1: Variation of $\mathrm{Q}^{\text {th }}$ with $\mathrm{H}$ for Different Flumes
Chart 1 shows relation between upstream head $\mathrm{H}$ and theoretical discharge calculated from the equation (3), (4), (5) and (6) respectively for the different flumes. It shows that when flume size increases the value of coefficient also increases. The exponent $\mathrm{n}$ not varies as coefficient of discharge varies.

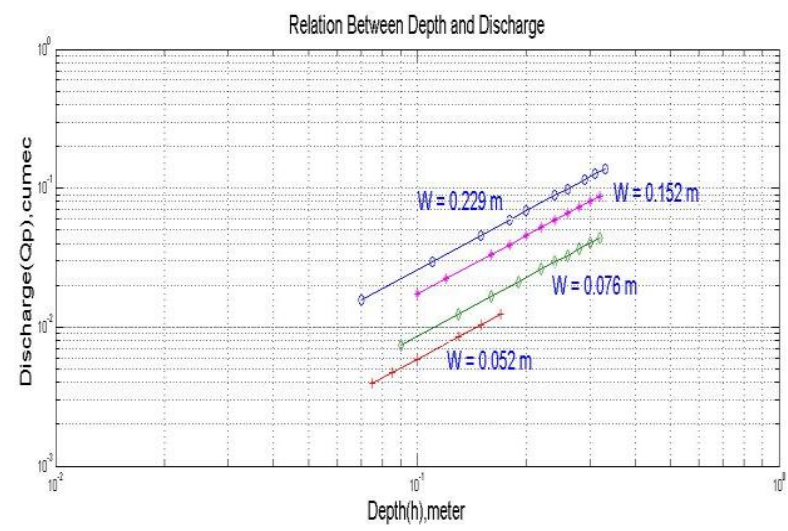

Chart 2: Variation of $\mathrm{Q}_{\mathrm{L}}$ with $\mathrm{H}$ for Different Flumes

Chart 2 indicates the relation between discharge $\mathrm{Q}_{\mathrm{L}}$ calculated from the equation (7) and upstream head $\mathrm{H}$.
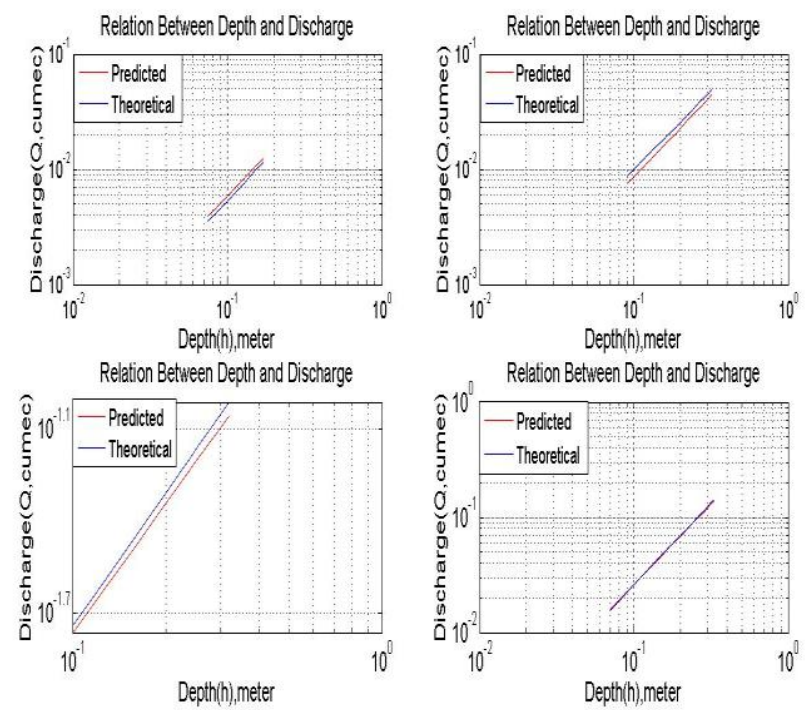

Chart 3: Comparison between Theoretical discharge and Predicted discharge

Chart 3 shows the comparison between theoretical discharges calculated from experimental values of coefficient and exponent and Predicted discharge calculated from equation (7) for the different flume size. Fig. 5 shows that predicted discharge lies near to theoretical discharge and it can be say that equation (7) gives much accuracy for discharge measurement. Chart 4 represents the comparison between 
discharge calculated from equation (7) and discharge calculated by the USDA.
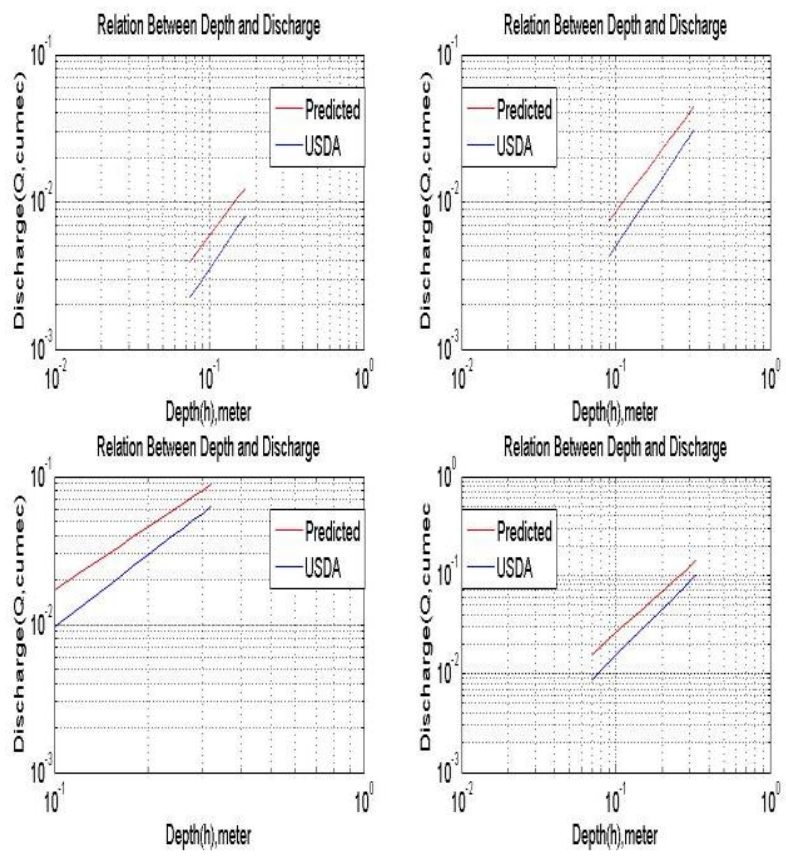

Chart 4: Comparison of Predicted discharge with USDA's method

\section{CONCLUSIONS}

The Parshall flumes having different throat width was tested and the results of the Experiments have been presented in this work. Discharge varies from $0.004 \mathrm{~m}^{3} / \mathrm{s}$ to $0.138 \mathrm{~m}^{3} / \mathrm{s}$ for the experiments. The measured depth-discharge relationships for free flow presented in this paper. New empirical formula has been developed for small size Parshall flume flumes which finally gives a combined equation applicable for free flow condition. Based on this study it is conceded out in this paper with conclusion that the discharge relation for different size of Parshall Flume is given as

$$
\mathrm{Q}_{\mathrm{L}}=2.85 \mathrm{~W} \mathrm{H}^{1.40}
$$

From the experimental results and proposed equations it is evident that it can measure discharge with a deviation of $\pm 7 \%$ for free flow condition.

Table 4: Free flow data observation

\begin{tabular}{|l|c|c|c|c|}
\hline $\begin{array}{l}\text { Flume } \\
\text { Size (m) }\end{array}$ & Test & $\mathrm{H}$, meter & $\mathrm{Q}_{\mathrm{a}} \mathrm{m}^{3} / \mathrm{s}$ & $\mathrm{Q}_{\mathrm{L}}, \mathrm{m}^{3} / \mathrm{s}$ \\
\hline & 1 & 0.075 & 0.00346 & 0.003944 \\
& 2 & 0.085 & 0.00458 & 0.004699 \\
0.052 & 3 & 0.10 & 0.00501 & 0.005941 \\
& 4 & 0.13 & 0.00740 & 0.008519 \\
\hline
\end{tabular}

\begin{tabular}{|c|c|c|c|c|}
\hline & 5 & 0.15 & 0.00933 & 0.010408 \\
\hline & 6 & 0.17 & 0.01215 & 0.012402 \\
\hline \multirow{10}{*}{0.076} & 1 & 0.09 & 0.00849 & 0.007445 \\
\hline & 2 & 0.13 & 0.01451 & 0.012450 \\
\hline & 3 & 0.16 & 0.01983 & 0.016654 \\
\hline & 4 & 0.19 & 0.02362 & 0.021179 \\
\hline & 5 & 0.22 & 0.02915 & 0.026005 \\
\hline & 6 & 0.24 & 0.03300 & 0.029373 \\
\hline & 7 & 0.26 & 0.03485 & 0.032856 \\
\hline & 8 & 0.28 & 0.04118 & 0.036449 \\
\hline & 9 & 0.30 & 0.04277 & 0.040145 \\
\hline & 10 & 0.32 & 0.05272 & 0.043941 \\
\hline \multirow{11}{*}{0.152} & 1 & 0.10 & 0.01803 & 0.017246 \\
\hline & 2 & 0.12 & 0.02291 & 0.022261 \\
\hline & 3 & 0.16 & 0.03309 & 0.033301 \\
\hline & 4 & 0.18 & 0.04826 & 0.039271 \\
\hline & 5 & 0.20 & 0.05211 & 0.045512 \\
\hline & 6 & 0.22 & 0.05809 & 0.052009 \\
\hline & 7 & 0.24 & 0.06213 & 0.058747 \\
\hline & 8 & 0.26 & 0.07333 & 0.065713 \\
\hline & 9 & 0.28 & 0.07885 & 0.072897 \\
\hline & 10 & 0.30 & 0.08486 & 0.802895 \\
\hline & 11 & 0.32 & 0.08956 & 0.087882 \\
\hline \multirow{10}{*}{0.229} & 1 & 0.07 & 0.01766 & 0.015769 \\
\hline & 2 & 0.11 & 0.02866 & 0.029691 \\
\hline & 3 & 0.15 & 0.04521 & 0.045836 \\
\hline & 4 & 0.18 & 0.05803 & 0.059165 \\
\hline & 5 & 0.20 & 0.05988 & 0.068568 \\
\hline & 6 & 0.24 & 0.07381 & 0.088507 \\
\hline & 7 & 0.26 & 0.10612 & 0.099002 \\
\hline & 8 & 0.29 & 0.13453 & 0.115355 \\
\hline & 9 & 0.31 & 0.13695 & 0.126645 \\
\hline & 10 & 0.33 & 0.15325 & 0.138229 \\
\hline
\end{tabular}

\section{REFERENCES}

[1] Abt, Steven R.and Staker Kenneth J. (1990) "RATING CORRECTION FOR LATERAL SETTLEMENT OF PARSHALL FLUMES" Journal of Irrigation and Drainage Engineering, ASCE, Vol. 116, No. 6

[2] Abt, Steven R., Florentin,. C. Bradley, Genovez, A. and Ruth, Bryan C.(1995) "SETTLEMENT AND SUBMERGENCE ADJUSTMENTS FOR PARSHALL FLUME" Journal of Irrigation and Drainage Engineering, ASCE, Vol. 121, No.5

[3] Amanda L. Cox, Christopher I.Thornton, Steven R. Abt, (2013."Supercritical Flow Measurement Using a Large Parshall Flume", Journal of Irrigation and Drainage Engineering, ASCE, 139(8) pp 655-662

[4] Bennett, R. S. (1972) "Cutthroat flume discharge relations." Water Management Technical Report No.16, Colorado Agricultural College, Fort Collins, $\mathrm{CO}$. 
[5] Boman,B. and Shukla S. (2006) "Water measurement for Agricultural Irrigation and Drainage System" Circular 1495, pp 1-12

[6] Blaisdell, Fred W.(1994) "RESULTS OF PARSHALL FLUME TESTS" Journal of Irrigation and Drainage Engineering, ASCE, Vol. 120, No. 2

[7] Borghei, S. M., Jalili, M. R. and Ghodsian, M. (1999) "DISCHARGE COEFFICIENT FOR SHARPCRESTED SIDE WEIR IN SUBCRITICAL FLOW" Journal of Hydraulic Engineering, ASCE, Vol. 125, No. 10

[8] Clemmens, A.J., Wahl, T.L., Bos,M.G. and Replogle ( 2001) "Water Measurement with Flumes and Weir" International Institute for Land Reclamation and Improvement / ILRI , publication 58

[9] Cone, V.M. (1917) “The Venturi Flume” Journal of Agricultural Research, Vol. 9 No. 4

[10] Inglis, C. C. 1928. "Notes on standing wave flumes and flume meter falls". Government of Bombay, Public Works Department Technical Paper No. 15

[11] Heiner, B. and Barfuss, Steven L.(2011) "Parshall Flume Discharge Corrections: Wall Staff Gauge and Centerline Measurements" Journal of Irrigation and Drainage Engineering, ASCE, Vol. 137, No. 12

[12] Howes, Daniel J., Burt, Charles M. and Sanders, Brett F. (2010) "Subcritical Contraction for Improved OpenChannel Flow Measurement Accuracy with an Upward-Looking ADVM" Journal of Irrigation and Drainage Engineering, ASCE, Vol. 136, No. 9

[13] Manekar Vivek L. , Prakash D. Porey., Ramesh N. Ingle (2007) "Discharge Relation for Cutthroat Flume under Free-Flow Condition" Journal of Irrigation and Drainage Engineering, ASCE, 133 (5) pp 495-499

[14] Parshall, R. L. (1928). "The Improved Venturi flume." Bulletin 336, Colorado Experiment Station, Colorado Agricultural College, Fort Collins, CO.

[15] Robinson,A.R. and Humpherys,A.S.(1968) “ Water control and measurement on Farm" ARS , Kimberly, Idaho, pp 828- 864

[16] Skogerboe, Gaylord V., Hyatt, M. Leon, England, Joe D., and Johnson, J. Raymond, (1966) "Measuring Water with Parshall Flumes", Reports. Paper 83.

[17] Skogerboe, Gaylord V.; Hyatt, M. Leon; and Eggleston, Keith O. (1967). "Design and Calibration of Submerged Open Channel Flow Measurement Structures: Part 1 - Submerged Flow" Reports. Paper 93.

[18] Smith, R.E. , Chery, D.L .Jr., Renard, K.G. and Gwinn, W.R. (1982) "Supercritical Flumes for measuring Sediment Laden Flow" USDA Technical Bulletin 1655.

[19] Temeepattanapongsa, S.,Merkley, G. P. Barfuss, S. L. and B. L. Smith (2013) "Generic Free-Flow Rating for Cutthroat Flumes" Journal of Hydraulic Engineering, ASCE, Vol. 139, No. 7
[20] Thornton, Christopher I., Smith, Brian A., Abt, Steven R. F. and Robeson, Michael D. (2009) "Supercritical Flow Measurement Using a Small Parshall Flume" Journal of Irrigation and Drainage Engineering, ASCE, Vol. 135, No. 5

[21] Torres, Alfonso F. and Merkley, Gary P. (2008) "Cutthroat Measurement Flume Calibration for Free and Submerged Flow Using a Single Equation" Journal of Irrigation and Drainage Engineering, ASCE, Vol. 134(4)

[22] Wright,steven J. , Tullis. Blake P. and Long, Tamara M. (1994) "RECALIBRATION OF PARSALL FLUME AT LOW DISCHARGES "Journal of Irrigation and Drainage Engineering, ASCE, Vol.12 